\title{
Study Advances on Vertical Greenery System
}

\author{
Xiaoli HOU and Li XUE* \\ College of Forestry and Landscape Architecture, South China Agricultural University, 510642 \\ Guangzhou, China \\ *Corresponding author: Li Xue; forxue@scau.edu.cn
}

Keywords: vertical greenery systems; type; acoustic insulation; thermal; temperature; $\mathrm{CO}_{2}$ sequestration; microclimatic layer

Abstract. For high-density urban environments, vertical greenery is often employed as one of feasible alternatives of environmental improvement. Vertical greenery systems (VGS) are being served as an interesting measure to improve the quality of life and urban environments, but only a few studies have examined overall performance of VGS. Vertical greenery has potential benefits, including reducing the surface temperature of buildings facades and diurnal temperature fluctuation, alleviating Urban Heat Island and noise pollution, reducing g heat flux to the building and energy cost, transforming the urban landscape and enhancing visual effect and so on. This paper provides a literature review for VGS studying, including VGS classification and their effects on acoustic insulation, thermal, air flow and temperature, energy performance, $\mathrm{CO}_{2}$ sequestration and microclimatic layer.

\section{Introduction}

For compact city areas with inadequate land to urban green spaces, vertical greenery is often employed as feasible alternatives [1]. Vertical greenery systems (VGS), known as the greening of the facade of building walls [2]. VGS have a positive influence on the comfort and well-being in and around the building [3], can offer numerous ecological and environmental benefits as innovative components of urban design and increase greenery in built environments lacking green areas [4-5], which is still a relatively new discipline and has become one of the most rapidly developing fields in the worlds of ecology, horticulture and the built environment [2]. Many factors affect performance of VGS, such as plants species, substrate type, orientation and dimensions and so on. The aim of studies about VGS is to finding better ways for enhancing these performances to improve environmental and people's life quality [6].

VGS serve as a natural barrier where plants absorb a significant amount of solar radiation for their growth and biological functions and prevents solar excessive sunlight, which reduce outside temperature of the building and reduces sound levels, cool the respective internal spaces [7], and remove carbon dioxide $\left(\mathrm{CO}_{2}\right)$ from the atmosphere by carbon (C) uptake [8]. Therefore, VGS improve the building's efficiency, ecological and environmental and human health and also protect buildings from environmental stressors such as sun and acid rain [9-10].

\section{Classification of VGS}

Regarding vertical greenery systems, also called living walls, basically can be classified into three main types. The first type is traditional green walls where climber plants use the facade material as a support. The second type uses geotextile felts to support plants without a substrate, while the third type makes up of plants or grass embedded in a specific cladding structure anchored on the building facade [11]. In the first typology, climber plants use the facade material as a support to creeps over the building envelope; and perimeter flowerpots when hanging shrubs are planted around the building as a part of the composition of the facade to constitute a green curtain [12]. In the second typology, living walls are made of geotextile felts. Sometimes pre-cultivated, which are fixed to a vertical support or on the wall structure [13]. The panels and geotextile 
felts provide support to the vegetation formed by upholstering plants, ferns, small shrubs, and perennial flowers, among others; in the third typology, the substrate and the plants are placed in modules (boxes), either plastic or metal, sometimes pre-cultivated, which are fixed to a vertical support structure or directly to the building facade wall [14].

\section{Acoustic Insulation of Vertical Greenery}

Generally, the sound insulation effect of vegetation is considered to be small in urban environments, with the reductions ranging from 5 to $10 \mathrm{~dB}$ [14]. Some researchers found that vertical greenery systems exhibited a good noise reduction than other common building materials with the reductions ranging from 5-10 $\mathrm{dB}$ or even higher with better constructive systems, and its effects on low to middle frequencies are more significant [15].

The green wall has a similar or better acoustic absorption coefficient than other common building materials [14]. Wong et al. reported that the sound absorption coefficient of the greenery system was higher compared with other building materials and furnishings [16]. Since green wall is more efficient absorbing sound, it could be used very effectively in public places for instance restaurants, hotels, and halfway up the street to the passage of people [14]. Many factors affect the function of green wall in sound insulation, structure, materials, type, moisture content of the substrate, plant species, the screen dimensions, and the shape and location with respect to the source of the noise have an impact on the acoustic performance of vertical greenery systems [16]. Moreover, the absorption coefficient increases with increasing frequencies and with larger greenery coverage [14].

\section{Thermal of Vertical Greenery}

Vertical greenery system is an excellent way of saving energy [7]. Areas with vertical vegetation are cooler than light-coloured bricks, walls and black surfaces that are typically found in urban areas, because vegetation can alleviate Urban Heat Island (UHI) directly by shading buildings from solar radiation and through evapotranspiration cooling [2,17], reducing solar reflection and re-radiation to atmosphere [2]. The shading effect of vertical greenery systems results in an $8 \%$ reduction in annual energy consumption [18]. Projected energy savings rang from $90 \%$ to $35 \%$ for various cities [19]. Vegetation can dramatically reduce the maximum temperatures of a building by shading walls from the sun, with daily temperature fluctuation being reduced by as much as 50\% [20]. In a Canadian research, Bass and Baskaran found that vertical greenery systems in an urban environment reduced surface temperatures sufficiently [18].

The factors influencing energy exchange and transmission of a vertical greenery ecosysteminclude weather condition, plant physiological function, and building structure. For example, the south green wall can transfer much more heat flux through the vertical greenery by strong canopy evapotranspiration. The south green wall has the lowest heat flux absorbance and heat flux loss in comparison with the north green wall [21]. Vines can reduce the temperature of a veranda with south-western exposure in Japan [22].

\section{Air Flow and Temperature of Vertical Greenery}

For high-density urban environments, greenery can help to cool the air and provide shade [1]. Great quantities of solar radiation will be absorbed due to plant growth and their biological functions by constructing green facades [3]. Significant amounts of radiation are used for photosynthesis, transpiration, evaporation and respiration [23]. Therefore, the climate between the building wall and green facade has the characteristics of low temperature and high humidity [13]. The surface temperatures of vertical greenery systems were cooler than common building materials such as light-coloured bricks, walls and black surfaces [18], resulting in temperature reduction of in the building interior [11]. 
The cooling effect takes place due to the water evapotranspiration process from the plants and substrates. Moreover, the wall's building facade as cooling effect can reduce surface temperatures [12]. Vertical greenery systems based on planter boxes can effectively hinder wind and reduce wind velocity, which affects the thermal resistance of the building envelope and thus his efficiency. Generally vertical greenery systems with an air cavity of 40-60 mm could work as a stagnant air layer [13].

A part of (5-30\%) the remaining solar radiation is passing through the leaves and affects the internalclimate of buildings when it passes the facade [3]. Bartfelder and Köhler reported that a temperature reduction at the green facade in a range of $2-6^{\circ} \mathrm{C}$ compared with the barewall. In the humid climates of Hong Kong [24], vertical greenery systems decreased a maximum temperature of $8.4^{\circ} \mathrm{C}$ [19]. The temperature difference at the wall surface between a greened and non-greened facade is approximately $6^{\circ} \mathrm{C}$ in a study in Germany. Wong et al. founded a maximum reduction of $11.6^{\circ} \mathrm{C}$ by a vertical greening wall in Hortpark (Singapore) [2]. Wong et al. stated that vertical greenery systems reduced a maximum temperature of $11.5^{\circ} \mathrm{C}$ at building facades in tropical climates [25].

\section{Energy Performance of Vertical Greenery}

Vertical greenery systems have ability to reduce energy consumption of buildings and to contribute to optimizing VGS thermal performances. Direct solar radiation and green shading are among the most important factors affecting the thermal performance of building envelopes [6,11]. Vertical greenery systems lower energy demand and cool building interiors or exterior through blocking incoming solar radiation and minimizing the amount of energy into the concrete facade $[3,25]$. The National Research Council of Canada found that the shading effect reduce the energy cooling load and usage of fans by $20 \%$ and $23 \%$, resulting in an $8 \%$ reduction in annual energy consumption [18], Mazzali et al. found that the VGS reduced the energy cooling load significantly [11], decreased the immediate outdoor temperature by $5.5-8{ }^{\circ} \mathrm{C}$ and a corresponding energy by $50-70 \%$ [26].

The shading effectively reduces external surface temperature, the direct solar radiation and heat flux entering interior, finally decrease of the consumption of summer cooling energy [11]. The leaf area index has effect on shading, because it has a linear relationship with shading coefficient, which means a higher coverage of greenery resulting in a better shading effect and a greater thermal insulation [25]. In addition, the solar absorption amount and emissivity of leaves and the transpiration of plants increase heat losses [11].

\section{$\mathrm{CO}_{2}$ Sequestration of Vertical Greenery}

The vertical greenery is a small carbon pool in city areas, and has certain carbon sequestration. The $\mathrm{CO}_{2}$ sequestration can be evaluated by a set of herbaceous species commonly used in VGS. A dynamic model can be used to evaluate $\mathrm{CO}_{2}$ sequestration in VGS, which included the processes from planting and growth of perennial herbaceous plants to the end of their lives, also considering return of carbon to soil elsewhere after composting the green residues. The species and biological properties decide carbon sequestration in plant tissues [4]. Studies on $\mathrm{CO}_{2}$ sequestration of vertical greenery systems are few. Marchi et al. selected herbaceous species as vertical greenery that hypothetically installed on a building facade [4], to evaluated $\mathrm{CO}_{2}$ sequestration and permanent removal of $\mathrm{C}$, and his model predicts that carbon dioxide accumulation increase continually in the VGS over time, indicating a $98 \mathrm{~m}^{2}$ VGS captures average carbon dioxide sequestration about 13.41-97.03 $\mathrm{kg} \mathrm{CO}_{2}$ per year. Therefore, VGS is a feasible measure for climate change mitigation in urban areas.

\section{Microclimatic Layer of Vertical Greenery}

Alexandri and Jones showed that VGS highly affect microclimate, especially in hotter and drier climate, which are regarded as valuable ways improving buildings and urban environment [19]. In particular, VGS 
have a stronger effect on urban temperature and energy [27], which may be changed by the adaptive properties and the arrangement of plants [28].

Vertical greenery acts as passive system effect environment through four mechanisms: the shadow of vegetation [29], the insulation of vegetation and substrate, the evapotranspiration and cooling, and the barrier effect to the wind [14]. The process of cooling by plant evapotranspiration is a result of its metabolic processes, in which plants select to absorb short-wave radiation to carry out photosynthesis, assimilate minerals from the outside to keep respiration [30], and affect surface temperature and flow conditions by shading [28]. The decrease in surface temperature finally lead to a lower cooling of building interior [11,13], and avoid diurnal temperature fluctuation due to exposure from direct solar radiation [31]. In addition, the absorption of $\mathrm{CO}_{2}$ through plant photosynthesis can help remit greenhouse effect and the green walls enable more reasonable utilization of water resources [28], also help insulate noise pollution [32], improve the quality of urban storm water discharge [33].

Urban Green Spaces (UGS) acts as lungs absorb pollutants and releasing oxygen, brings out nature's clean and safe amenity spaces, balances the city's environment [22], contributes to physical and mental health [34]. VGS as an important part of UGS, despite they are difficult to maintain due to their need for constant irrigation and fertilization [35], the existing researches on VGS indicate that have great potential to improve environment and buildings [7].

\section{Acknowledgements}

This work was financially supported by the Foundation of Guangdong Forestry Department (No. 4400-F11031, 4400-F11055).

\section{References}

[1] C.L. Tan, N.H. Wong, and K.J. Steve, Effects of vertical greenery on mean radiant temperature in the tropical urban environment. Landscape and Urban Planning. 127 (2014) 52-64.

[2] N.H. Wong, A.Y.K. Tan, Y. Chen, K. Sekar, P.Y. Tan, D. Chan, K. Chiang, and N.C. Wong, Thermal evaluation of vertical greenery systems for building walls. Building and Environment. 45 (2010) 663-672.

[3] K. Perini, M. Ottelé, A.L.A. Fraaij, E.M. Haas, and R. Raiteri, Vertical greening systems and the effect on air flow and temperature on the building envelope. Building and Environment. 46 (2011) 2287-2294.

[4] M. Marchi, R.M. Pulselli, N. Marchettini, F.M. Pulselli, and S. Bastianoni, Carbon dioxide sequestration model of a vertical greenery system. Ecological Modelling. (2014)7282-7293.

[5] M. Köhler, Green façades: a view back and some visions. Urban Ecosystems. 11 (2008) 426-436.

[6] T. Safikhani, A.M. Abdullah, D.R. Ossen, and M. Baharvand, A review of energy characteristic of vertical greenery systems. Renewable and Sustainable Energy Reviews. 40 (2014) 450-462.

[7] B. Jaafar, I. Said, M.N.M. Reba, and M.H. Rasidi, Impact of vertical greenery system on internal building corridors in the tropic. Procedia - Social and Behavioral Sciences. 105 (2013) 558-568.

[8] K. Shiah, J.W. Kim, An investigation into the application of vertical garden at the new SUB atrium. The University of British Columbia, APSC 261, 33, pp. Report (2011).

[9] E. Oberndorfer, J. Lundholm, B. Bass, R.R. Coffman, H. Doshi, N. Dunnett, S. Gaffin, M. Köhler, K.K.Y. Liu, and B. Rowe, Green roofs as urban ecosystems. Ecological strucutures, functions and services. 57 (2007) 823-833.

[10] N.H. Wong, A.Y.K. Tan, P.Y. Tan, K. Chiang, and N.C. Wong, Acoustics evaluation of vertical greenery systems for building walls. Building and Environment. 45 (2010) 411-20. 
[11] U. Mazzali, F. Peron, P. Romagnoni, R.M. Pulselli, and S. Bastianoni, Experimental investigation on the energy performance of living walls in temperate climate. Building and Environment. 64 (2013) 57-66.

[12] G. Pérez, J. Coma, I. Martorell, and L.F. Cabeza, Vertical Greenery Systems (VGS) for energy saving in buildings: A review. Renewable and Sustainable Energy Reviews. 39 (2014) 139-165.

[13] G. Pérez, L. Rincón, A. Vila, J.M. González, and L.F. Cabeza, Green vertical systems for buildings as passive systems for energy savings. Applied Energy. 88 (2011) 4854-4859.

[14] Z. Azkorra, G. Pérez, J. Coma, L.F. Cabeza, S. Bures, J.E. Alvaro, A. Erkoreka, and Urrestarazu M, Evaluation of green walls as a passive acoustic insulation system for buildings. Applied Acoustics. 89 (2015) 46-54.

[15] The National Physical Laboratory. Kaye and Laby tables of physical \& chemical constants. <http://www.kayelaby.npl.co.uk/> [accessed 14.05.14].

[16] N.H. Wong, A.Y.K. Tan, P.Y. Tan, A. Sia, and N.C. Wong, Perception studies of vertical greenery systems in Singapore. Journal of Urban Planning and Development. 136 (2010) 330-338.

[17] E.G. McPherson, Preserving and restoring urban biodiversity: cooling urban heat islands with sustainable landscapes. University of Massachusetts Press. (1994) 151-72.

[18] B. Bass, and B. Baskaran, Evaluating rooftop and vertical gardens as an adaptation strategy for urban areas. Institute for Research and Construction. National Research Council. (2003).

[19] E. Alexandri, and P. Jones, Temperature decreases in an urban canyon due to green walls and green roofs in diverse climates. Building and Environment. 43 (2008) 480-93.

[20] N. Dunnett, N. Kingsbury, Planting green roofs and living walls. Portland, USA: Timber Press.(2008)

[21] C.Y. Jim, H.M. He, Estimating heat flux transmission of vertical greenery ecosystem. Ecological Engineering. 37 (2011) 1112-1122.

[22] A. Hoyano. Climatological uses of plants for solar control on the effects on the thermal environment of a building. Energy and Buildings. 11 (1988) 181-189.

[23] P. Krusche, M. Krusche, D. Althaus, and I. Gabriel, Herausgegeben vom umweltbundesamt. Bauverlag. (1982)

[24] F. Bartfelder, M. Köhler, Experimentelle untersuchungen zur function von fassadenbegrünungen, Dissertation TU Berlin 612S. (1987)

[25] N.H. Wong, A.Y.K. Tan, P.Y. Tan, and N.C. Wong, Energy simulation of vertical greenery systems. Energy and Buildings. 41 (2009) 1401-1408.

[26] S.W. Peck, C. Callaghan, B. Bass, and M.E. Kuhn, Greenbacks from Green Roofs: Forging a New Industry in Canada. Ottawa, Canada, Canadian Mortgage and Housing Corporation (CMHC). (1999)

[27] R.M. Pulsellia, F.M. Pulsellia, U. Mazzalib, F. Peronb, and S. Bastianoni, Energy based evaluation of environmental performances of Living Wall and Grass Wall systems. Energy and Buildings. 73 (2014) 200-211.

[28] T. Šuklje, S. Medved, and C. Arkar, An experimental study on a microclimatic layer of a bionic facade inspired by vertical greenery. Journal of Bionic Engineering. 10 (2013) 177-185.

[29] J. Coma, G. Pérez, C. Solé, A. Castell, and L.F. Cabeza, New green facades as passive systems for energy savings on buildings. Energy Procedia. 57 (2014) 1851-1859. 
[30] H.G. Jones, Plants and microclimate: A quantitative approach to environmental plant physiology. Cambridge: Cambridge University Press. (1992).

[31] N. Dennett, N. Kingsbury, Planting green roofs and living walls (Vol. 254) Portland, OR: Timber Press.(2004)

[32] T. Van Renterghem, M. Hornikx, J. Forssen, and D. Botteldooren, The potential of building envelope greening to achieve quietness. Building and Environment. 61 (2013) 34-44.

[33] C.Y. Jim, Assessing climate-adaptation effect of extensive tropical green roofs in cities. Landscape and Urban Planning. 138 (2015) 54-70.

[34] T.B. Levent, P. Nijkamp, Urban green space policies: A comparative study on performance and success conditions in European cities. In 44th European congress of the European regional science association. (2004)

[35] R.D. Berghage, D. Beattie, A.R. Jarrett, C. Thuring, F. Razaei, and T.P. O'Connor, Green roofs for storm water runoff control. EPA/600/R-09/026. Washington, DC: US Environmental Protection Agency. (2009) 